\title{
The Development of Gas Energy Potential of Coal Deposits as the Necessary Step Towards the Russian Coal Industry Modernization
}

\author{
Lazarenko Sergey N. ${ }^{\mathrm{a}}$, Dubov Georgiy M. ${ }^{\mathrm{b}}$, Shirokolobova Anastasia G. ${ }^{\mathrm{c}}$ \\ T. F. Gorbachev Kuzbass State Technical University \\ Kemerovo, Russian Federation \\ as.lazarenko2009@mail.ru; ${ }^{b}$ nikokem@mail.ru; ${ }^{c}$ nastja_shirokolo@ rambler.ru
}

\begin{abstract}
The paper describes the current state of works on the gas component development of the energy potential of coal deposits in Russia. The development of the following technologies is being considered: underground coal gasification; industrial methane extraction from coal deposits; methane extraction of abandoned coal mines; methane degasification of working mines; "Coalgas" technology. It is noted that the underground coal gasification technology has the most favorable prospects for its development in Russia. The description of the specific plans for practical application of some discussed technologies in the industrial environment of the largest coal-mining region of Russia - the Kuznetsk Basin - is given. It is confirmed that the effective use of the energy potential of the gas coal deposit is the required (even more - obligatory) component of the development process of the region; the implementation of this principle in practice will become one of the decisive factors in Russian coal industry modernization in accordance with call of times.
\end{abstract}

Keywords - underground coal gasification; methane; mine; gas utilization; degasification; energy potential.

\section{INTRODUCTION}

This template, modified in MS Word 2007 and saved as a "Word 97-2003 Document" for the PC, provides authors with most of the formatting specifications needed for preparing electronic versions of their papers. All standard paper components have been specified for three reasons: (1) ease of use when formatting individual papers, (2) automatic compliance to electronic requirements that facilitate the concurrent or later production of electronic products, and (3) conformity of style throughout a conference proceedings. Margins, column widths, line spacing, and type styles are built-in; examples of the type styles are provided throughout this document and are identified in italic type, within parentheses, following the example. Some components, such as multi-leveled equations, graphics, and tables are not prescribed, although the various table text styles are provided. The formatter will need to create these components, incorporating the applicable criteria that follow.

\section{SUBJECT OF RESEARCH}

The authors believe that in Russia now there are a number of special (alternative) coal mining technologies to realize the gas energy potential of the deposits, namely:
- underground coal gasification;

- industrial methane production from coal deposits;

- methane extraction of abandoned coal mines;

- methane degasification of working mines;

- "Coalgas" technology.

Fig. 1 gives, as a demonstrative example, a diagram of gas production technologies of coal fields' development and objects of their applications.

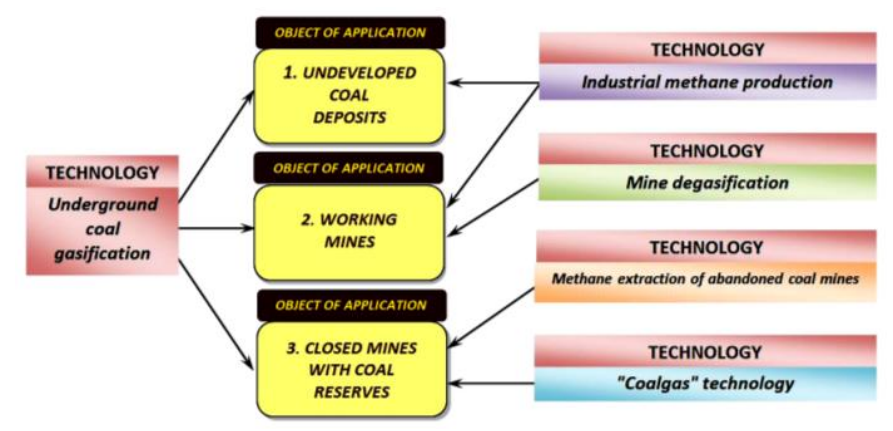

Fig. 1. Gas production technologies of coal fields' development and objects of their applications

Today underground coal gasification and industrial extraction of methane from coal deposits have the greatest technological potential. Moreover, the technology of underground coal gasification (UCG) has more favorable conditions for successful development in coal regions [1].

The prospects for the development of these technologies in the largest coal region of Russia - the Kuznetsk Basin are discussed hereafter.

\section{RESULTS AND DISCUSSIONS}

The administration of the Kemerovo region in 2012 decided and developed a program for the creation of regional innovation territorial coal-chemical cluster, designed to intensify the development of industrial and research base for deep coal processing. The above program, among other things, declared the intention of the development of alternative technologies of Kuzbass coal deposits development by means of underground coal gasification. 
Together with the idea development to build coal-chemical cluster in the region, T. F. Gorbachev Kuzbass State Technical University has developed a proposal for the implementation of the investment project, which aim is to build a pilot enterprise of underground coal gasification in the Kemerovo region.

Implementation of the project is possible in three versions:

1. The construction of the underground coal gasification enterprise, the end product of which will be low or intermediate combustible gas of underground coal gasification, used as energy row material (bunker oil). The construction cost of such type of enterprise, with production capacity 1.0 billion $\mathrm{m}^{3}$ of combustible gas per year with a calorific value of $4 \mathrm{~mJ} / \mathrm{m}^{3}$, is estimated at $450-500$ million rubles.

2. The autonomous mining and energy complex construction on the basis of underground coal gasification, where electric and heat energy will be the end product. The approximate cost of this complex is about 2.2 billion rubles; in its structure it will unite the company for coal seams gasification and gas turbine power plant with an electrical capacity of $50 \mathrm{MW}$, which will work on underground coal gasification gas, produced by the complex itself. Estimated cost of produced electricity will be approximately $1.3-1.5$ rubles / $\mathrm{kW}$ per hour.

3. The coal-chemical complex construction on the basis of underground coal gasification, where a variety of valuable chemical goods will be the end product, including synthetic liquid fuel. This type of enterprise of underground coal gasification is the most expensive in terms of investment, but the most attractive and promising in the economy demand aspect.

It is believed that such production by means of underground coal gasification technology will successfully be built into the system of coal-chemical cluster of the Kemerovo region.

It is possible to say that there are very good prospects for the construction of the discussed enterprise in the Kemerovo region. On the one hand, this is due to the existence of 40year-old experience of coal underground gasification technology application in Kuzbass (for example South Abinsk station "Podzemgas" in Kiselevsk, which functioned between 1955 and 1996), and on the other hand - due to critical need for clean and inexpensive gaseous energy row material for the region's energy. Besides, in case of construction of the underground coal gasification enterprise the released natural gas of appropriate volume, entering to the Kemerovo region from the Tyumen region, can be used for other purposes, including gasification of the residential sector.

Up today new, much more refined version of the gasification technology of coal seams was developed, which will allow to develop this technology on a new, higher technical level and at the same time, to receive combustible gas with higher calorific value and lower cost [2].

The authors of the article recommend to build the production in Kiselevsk on the basis of coal reserves of CJSC "Poliana" (the former mine "Krasnokamenskia") of JSC
"TalTEK" as the leader enterprise of the underground coal gasification in the Kemerovo region. Underground mining is completely stopped at this plant so far (due to its unprofitability), but millions of tons of high-calorie coal reserves are left in the depths of the mine [3]. The preliminary analysis of these reserves, carried out by the experts of KuzSTU, showed that most of them can be successfully developed by underground gasification method with a sufficient level of profitability. It should be noted that, the named coal company is interested in the search for the ways of real modernization of the coal deposits development technology.

There are other options for construction of enterprises of underground coal gasification in the Kemerovo region. Thus, construction of the production can be carried out in Promyshlennovskiy area on Ushakovskiy coal deposit. The construction of energy-technological complex "Serafimovskiy" with deep coal processing, involving the use of traditional (surface) coal gasification, is proposed in the same area by the above mentioned Program of coal-chemical cluster development in the Kemerovo region. It should be noted that, according to estimations the prime costs of chemical products, obtained by gas processing of underground coal gasification, will be significantly lower than the cost of similar chemical products, produced from extracted coal (i.e. including production cost) and subjected to the subsequent gasification at specific units.

The project of production to get gas of underground coal gasification is profitable and provides the return of invested funds with the profits derived from the products sale.

Specialists of the Kuzbass State Technical University are ready to provide scientific and engineering support for the implementation of this investment project, both in terms of the development of the project of construction of underground coal gasification enterprise, and during its subsequent development.

Today underground coal gasification is the only environmentally acceptable technology of coal deposits development. Thus, earth's surface is not practically disturbed under underground gasification in contrast to conventional coal mining methods. In addition, gas, produced underground and extracted to the surface from wells, is - unlike coal environmentally friendly fuel.

The UCG technology has social efficiency; all technological operations are carried out from the surface under the development of coal deposits by this method, this provides safe work to workers, and consequently, eliminates miners' deaths. Another aspect of social efficiency of the project is the creation of hundreds of new workplaces.

The areas of possible use of underground coal gasification gas are sufficiently diverse (Fig. 2).

Among the areas of underground coal gasification gas utilization the possibility of chemical processing of gas should be highlighted. The UCG gas has a unique composition, which allows organizing a whole range of chemical industry products of all sorts on the basis of its processing, including the production of synthetic liquid fuel. 


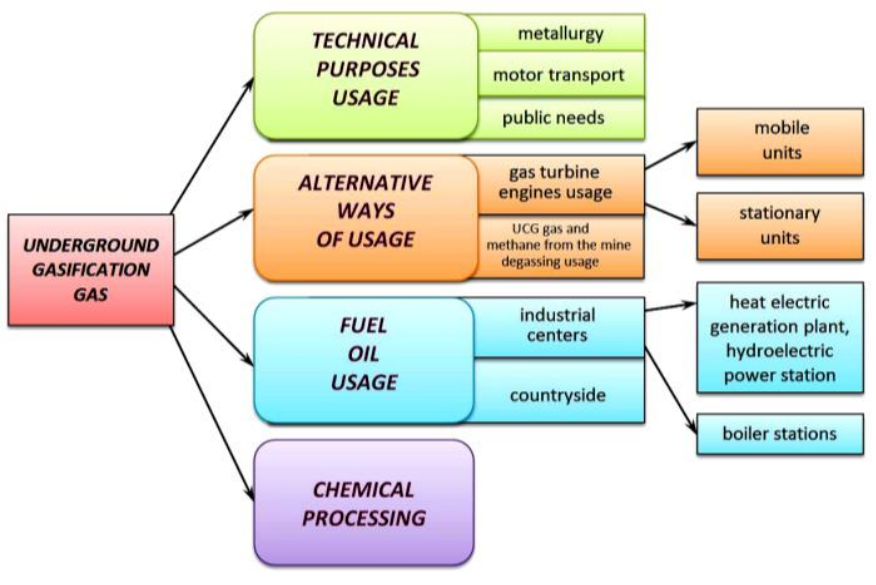

Fig. 2. Ways of possible underground coal gasification gas usage

Underground coal gasification gas, unlike natural gas, contains a number of additional components in its structure: benzene hydrocarbons, coal tar, phenol, methane, olefin, acetylene and etc. Thus, it is possible to obtain raw material for production of surface active substances, soot, solvents, dyes, polymers, monomers, naphthalene, benzene etc. from coal tar after its hydrogenation (Fig.3) [3].

Special mention should be given to possibility of getting artificial liquid fuels from gas produced by underground coal gasification, which can be synthesized by catalytic conversion of carbon monoxide and hydrogen.

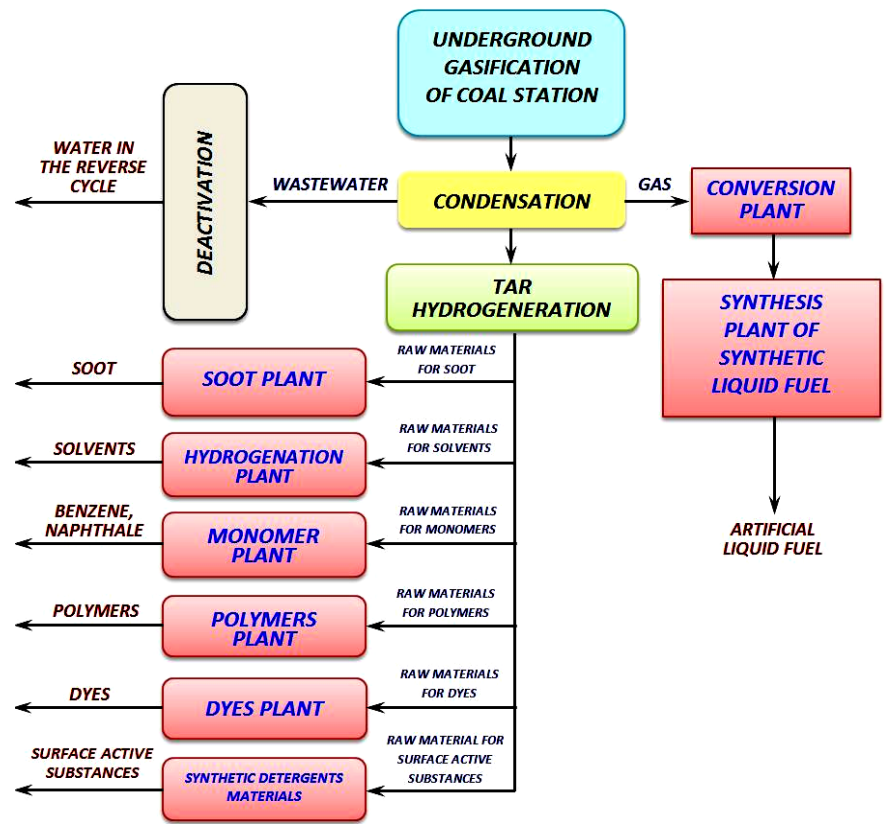

Fig. 3. Possibilities of chemical processing of underground coal gasification products
The gas temperature at the outlet of the gas production well is $600-700^{\circ} \mathrm{C}$ under underground coal gasification. This means that not only generating gas, thermal energy, raw materials for the chemical industry, but also valuable or toxic elements can be obtained from these seams. It is primarily, rhenium $(\mathrm{Re})$, arsenic (As), mercury $(\mathrm{Hg})$, selenium $(\mathrm{Se})$ and platinum $(\mathrm{Pt})$.

These valuable ( $\mathrm{Re}, \mathrm{Se}, \mathrm{Pt})$ and toxic (As, $\mathrm{Hg}$ ) elements will be in a vapor state under underground coal gasification, in the form of volatile compounds, as well as in composition of dust and aerosols of solid particles. Today, a number of technical solutions have been developed; these solutions are intended to extract valuable and toxic elements from the underground coal gasification gases [4].

Burning dumps, coal boiler, and open pits are the main sources of air pollution using traditional methods of coal mining.

According to the described method [5] the amount of 0.09 to 0.282 tons of dust (per each dust ton of an explosive element in dependence on its type and specific consumption) and from 0.001 to 0.104 tons of carbon oxides are emitted in the air from open pits.

When mining and stripping equipment of different types is used (excavators, bulldozers, conveyors, belt elevators and dumpers) dust emissions are in amount of 200 to $3000 \mathrm{~kg} / \mathrm{t}$ of coal, with account of dust suppression, and without dust suppression dust emissions are $7000 \mathrm{~kg}$.

Rocks dumps, especially burning ones are very strong air pollutants, as $\mathrm{CO} 0.8-1.0 ; \mathrm{CO}_{2} 2-7.5 ; \mathrm{O}_{2}$ 0.03-0.1; $\mathrm{H}_{2} \quad 0.02$; $\mathrm{NO}_{\mathrm{x}}$ 0.03-0.13 tons per day are emitted into the air along with dust.

These scales of emissions significantly affect the ecological situation in coal-mining regions.

Underground coal gasification process allows preventing emissions and airing pollution under gas production in leak free mode. The protective pillars are kept and exhausted wells are eliminated to avoid gas penetration on the surface.

According to data [6] showed in table 1, the transition of coal-fired boilers to underground coal gasification gas will completely prevent the emissions of solid matter and ash storage and allocation of land for ash dumps. Sulfur dioxide emissions will be reduced by 4-5 times, and nitrogen oxides emissions will be reduced by 2-3 times.

TABLE I. HAZARDOUS SUBSTANCES EMISSIONS

\begin{tabular}{|c|c|c|}
\hline \multirow{2}{*}{$\begin{array}{c}\text { Emission types, } \mathbf{~ k g} / \mathbf{t} \\
\text { reference fuel }\end{array}$} & \multicolumn{2}{|c|}{ Types of combustible fuel } \\
\cline { 2 - 3 } & Coal & UCG gas \\
\hline Ash & $13,7-17,23$ & - \\
\hline Sulfur dioxide & $6,7-9,0$ & 1,6 \\
\hline Nitrogen oxides & $1,03-4,93$ & $0,2-1,44$ \\
\hline $\begin{array}{c}\text { Total aggregate } \\
\text { emissions: }\end{array}$ & $23,43-33,13$ & $0,2-1,44$ \\
\hline
\end{tabular}

Economic evaluation of underground coal gasification in comparison with the process of Lurgi in ground gasifier showed, that gas produced in Lurgi process, is almost 
1.5 times more expensive than gas produced from underground coal gasification (UCG) at $100 \%$ capacity of the production unit.

By increasing the capacity of the unit for gas production by Lurgi method, its value decreases from 100 to 74 dollars, while under underground coal gasification its value decreases respectively from 59 to 50 dollars per $1,000 \mathrm{~m}^{3}$ of pipeline gas.

Figure 4 shows the comparative results of economic calculations. In the case of underground coal gasification the coal seam depth was taken to be $300 \mathrm{~m}$, and capacity was taken to be $30 \mathrm{~m}$. In both cases the gas composition was taken to be the same. $\mathrm{O}_{2}$ of $98 \%$ and water vapor at pressure of about 4.0 MPa $\left(40 \mathrm{kgs} / \mathrm{cm}^{2}\right)$ were taken as air blast. Coal processing approximately 23 thousand tons per day was taken for maximum productivity of the factory. Synthetic pipeline methane is produced about 8 million $\mathrm{m}^{3}$ per day [7].

In contrast to underground coal gasification the prospects and efficiency level of commercial production of methane from coal deposits requires their practical confirmation in Russia, and in the Kemerovo region particularly (today methane resources are estimated at more than 13-20 trillion $\mathrm{m}^{3}$ in Kuzbass coal basin) [8].

Significant successful application of this technology in the USA and some other countries can be explained, on the one hand, by the extremely favorable geological conditions (especially the adhesive coal properties) for its implementation, which coal deposits of these countries have, and which Russian deposits do not have in most cases; and on the other hand this success can be explained by favorable investment climate of the United States economy, it allowed the large-scale investments to be done to implement this technology in practice; these investments were resulted in tens of thousands of deep wells drilling in a relatively short period of time.

The cost price of gas

USA dollars $/ 1000 \mathrm{~m}^{3}$

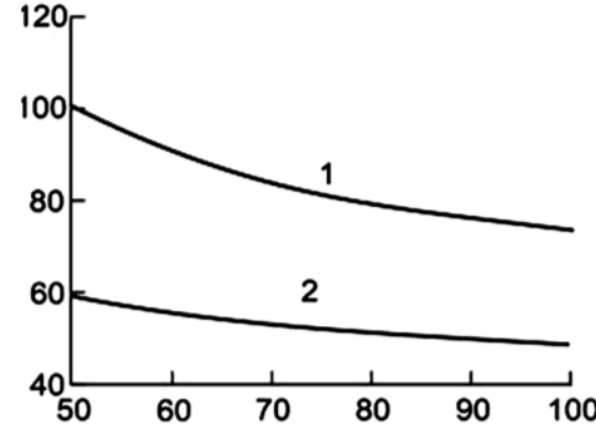

Fig. 4. Cost of synthetic gas in dependence on the plant performance: 1 - above surface gasification gas (by Lurgi);

2 - underground coal gasification gas (UCG).

Today there was a task, to a subsidiary company of "Gazprom" - LLC "Gazprom mining Kuznetsk" operating in Kuzbass in the past few years, set up to ensure by the year 2020 (according to the most recent data only to the year 2025) the level of annual production of coal methane in amount of
4 billion $\mathrm{m}^{3}$ [9]. (Although only a few years ago, the question looked much more ambitious, namely it were 20 billion $\mathrm{m}^{3}$ of methane produced annually by the year 2020).

Today, this company has drilled only a few dozen wells on the Taldinskoye deposit and Naryksko-Ostashkinskaya area of Kuzbass; and over the past five years, it was produced about 30 million $\mathrm{m}^{3}$ of methane. It should be mentioned that the pace of wells drilling as well as the average flow rate of methane are in times less than the extraction of methane from coal deposits of the United States. There is good reason to believe that even the promise of gas producers to increase the rate of wells drilling to a level of 130 wells per year will not be able to provide the declared level of production of methane from coal deposits in the Kemerovo region to the appointed date.

However, it should be emphasized that there is scientific and engineering need to research the ways and possibilities of application of commercial production of coal bed methane in Russia. It must be admitted that firstly, this technology adaptation to the conditions of Russian coal deposits was much more complicated and lengthy than it was expected; secondly this technology application will not be able to provide such productivity and such amounts of methane production on Russian coal deposits, as it had, for example, on San Juan deposits in the USA. However, there is confidence that the technology of industrial methane extraction from coal deposits is capable to find its niche and take its rightful place among modern technologies contributing to coal industry modernization in Russia.

If to discuss the list of coal deposits development technologies, sufficient place should be given to the method of extraction of methane from abandoned coal mines. When this technology is being implemented, there is the inextricable connection of two problems: on the one hand it is purely commercial task to obtain gaseous energy raw material; on the other hand it is the solution of the issue of public safety, in case of methane penetration from abandoned mines to the Earth's surface. It should be noted that the possibilities of actual usage of this technology is great: only in the Kemerovo region more than 40 mines were closed in the process of coal industry restructuring, the most mines developed coal seams with high gas content and at the time of mining operations close-down from 10 to $130 \mathrm{~m}^{3} /$ min of methane were emitted from these mines [10].

It is known that gas dynamic monitoring of methane and other gases is produced at many of these mines. This measure allowed to state that in many cases there is a vast amount of methane emissions in the underground workings. Such mines as "Siberian", "North", "named after Yaroslavskiy", "Westen", "North Maganak", "Nogradskaya", "Baydaevskaya", "Nagornayia", "Novokuznetskaya" and some others are considered to be environmentally hazardous according to methane, and in some cases the situation can be characterized as explosive dangerous. The process of gas penetration to the surface is technically uncontrolled. This fact actualizes the necessity and feasibility to implement the measures of methane recovery from the workings of abandoned coal mines. 
To realize successfully this technology in practice the study of scientific, engineering and methodical nature must be done, relating to the development of validated (and subsequently agreed with the authorities of Mining Inspectorate) methodology for assessing methane resources accumulating in the workings of closed mines and based on the direct measurements of the methane concentration measurement method of gas air mixture in the mine. Such assessment would clarify and expand the resource base of coal bed methane in terms of its actual and projected volumes in closed coal mines for possible industrial large scale extraction and subsequent utilization.

At the first stage it is possible to use foreign experience for the rapid implementation of this technology. Thus, Germany has the most significant experience in development and financing of such projects. Today there are already a number of technologies to extract and use methane mixture from abandoned mines [11].

Rather effective form of alternative energy in coal-mining regions is the utilization of coal mine methane, recovered by degasification systems of operating mines. Today to determine the methane content of coal both direct and indirect methods are used [12].

It is known that for significant amount of time coal mine methane is used as a fuel to generate electricity at gas plants in Germany, Australia, the UK, the USA and other countries. Over the past five years, methane recycling at power plants has been applied in China, Poland and the Ukraine. For example, in Australia the total capacity of power plants using coal mine methane is $215 \mathrm{MW}$, while in China it is $300 \mathrm{MW}$. In recent years such kind of works were started in Russia. As for the Kemerovo region, the example of a successful attempt to realize the project of CMM recycling in the generating station, made by CJSC "Coalmethan Service", is the project documentation development, construction and installation of a gas pipeline at the mine named after Kirov "SUEK-Kuzbass" in Leninsk-Kuznetsky. The final product is electricity, which is fed into the general electricity network. In addition, as part of CoMeth demonstration project in the mine "Komsomoletz" of OJSC "SUEK-Kuzbass" with the participation of A-Tec (Germany) and CJSC "Uglemetan Service" the project documentation has been developed for the recycling of methane-air mixture with a low and a high concentration of methane in the gas generator station. The project "Utilization of Coal Mine Methane in modular boiler system", implemented in 2008 at "Mine Krasnogorskaia" to produce thermal energy should be mentioned [13]. The above results of the first works in the field of recycling of degassing coal mine methane in the Kemerovo region have not received their practical continuation and development to the extent that they deserve for various reasons. However, these results allow saying that the present method of producing gas energy raw material in Kuzbass has very good prospects for successful development.

The technology "Coalgas" occupies special place in the list of gas producing technologies of mining deposits development. Scientific principles of this technology were developed in 1980s in the works of Moscow Mining Institute, under the supervision of academician V.V. Rzhevskiy [13]. The main feature of this technology was the implementation of direct combustion of coal reserves (not to be confused with gasification), left in the pit after excavation, used conventional technology (i.e., 20-50\% of the initially available recourses) with the gaseous products of coal combustion emitted to the surface, using the exhaust system of air feeding into the combustion source.

At the same time large-scale industrial experiments have been carried out, testing this method in practice. The most famous of them is the experiment of coal reserves combustion at the mine "Kireevsk-3" in the around Moscow coal basin. The main drawback of "Coalgas" technology is the fact that the gas, product produced by its usage, has a very low calorific value; this calorific value doesn't allow using it either as an energy raw material for gas turbines, either as conventional fuel oil. Therefore, the only possibility of useful application of this product is the utilization of this gas heat (with the subsequent use of the produced thermal energy to heat greenhouses, etc.). In addition, the question of the ability to manage and control the movement of the combustion chamber all-round the working mine space remains unsolved. For these and other reasons, works in this direction were in fact stopped. However, the technology "Coalgas" definitely has certain energy and technological potential. Interest to this technology can be revived at the present stage of development of coal industry in Russia, which, among other things, is characterized by a number of abandoned coal mines - and, as a consequence, the enlarged area of "Coalgas" technology possible implementation.

\section{CONCLUSION}

Fuel oil and natural gas are preferable to be used as the main fuel to generate electricity and thermal energy in today's prevailing energy conditions. This is more environmentally friendly, the process can be automated and does not require additional works to prepare the fuel for combustion and it is supposed to be cheaper. In other words it is not carbon.

However, the cheapness of national hydrocarbons as a fuel is relative: it is cheap in relation to the high prices of the world market. Russia may never know the true price of oil and natural gas due to the fact that hydrocarbons resources favorable for the development will end up before normal economic relations will be formed. Therefore, it is important to rethink the role of coal in the energy sector of Russia. The discussed clean coal technologies are aimed to this reason.

Russia, in some way, is behind the developed countries not only in the improvement and implementation of technologies in the coal fuel power generation, but also Russia begins to lose its priorities in the truly Russian underground coal gasification technology (UCG) due to prolonged inactivity during the last decade. This is unacceptable, since according to the information that [15] industry is provided by explored coal reserves for more than 400 years, the reserves of explored hydrocarbons (oil and gas) are much less.

Thus, the awareness of the fact that the efficient use of gas energy potential of coal deposits is a required component (and even more - obligatory one) of the development process of the 
coal deposits development, as well as the implementation of this principle in practice will be a decisive factor in Russian coal industry modernization in accordance with call of times.

\section{REFERENCES}

[1] Lazarenko S.N., Kovalev V.A. The directions of development of underground coal gasification technology. - Novosibirsk: Publishing House of the Siberian Branch of the Russian Academy of Sciences, 2015. $-150 \mathrm{p}$.

[2] Kreynin E.V., Lazarenko S.N. "Coal as a source of hydrocarbons", Coal, 2012, vol. 7. - P. 40-44.

[3] Zorya A.U., Kreynin E.V., Lazarenko S.N. "The prospects of development of underground coal gasification technology", Kuzbass Coal, 2009, vol. 5. - P. 74-77.

[4] Anferov B.A., Kuznetsova L.V. "Underground coal gasification - a perspective method of complex development of Kuzbass deposits". Vestnik Kuzbass. gosud. tehn. univ., 2013, 5(99). - P. 130-135.

[5] The collection of methods to calculate emissions of air pollutants, produced by different manufactures. 1, Gidrometizdat, 1986.

[6] Kreynin E.V. "Underground coal gasification as an environmentally friendly technology of its production and use", Mining informational and analytical bulletin, 2008, №4. - P. 256-262.

[7] Kreynin E.V. "Technical and economic perspectives of underground coal gasification", Mining informational and analytical bulletin, 2009, vol. 5. - P. 347-352.
[8] Shubina E.A., Lukyanov V.G. "The study of the natural gas content to extracte methane from coal seams in the industrial scale", Vestnik Kuzbass. gosud. tehn. univ., 2016, 1(113). - P. 3-11.

[9] OJSC "Gazprom" [Electronic resource]: [official. website] // 2003-2015. Access: URL: http: //www.gazprom.ru/about/production/extraction/ metan/, free - About coal gas production prospects in Russian (reference date $10 / 05 / 2016)$.

[10] Willenbrink B. "CBM Review: degassing development", World Coal, 2003. - V. 12, \#3. - P. 51-54.

[11] Meshcheryakov D.A. "Estimation of the magnitude and duration of the remaining gassing of closed mines", Mining informational and analytical bulletin, 2000, №7. - P. 322-324.

[12] Tailakov O.V., Tatsienko V.P., Kormin A.N., Smyslov A.I. "Evaluation of the effectiveness of core extractors when measuring the outgassing of methane from coal seams", J. Mining Science, 2015, \#6. P. 146-150.

[13] Tailakov O.V., Zastrelov D.N., Islamov D.V., Makeev M.P. "The introduction of coal-bed methane utilization systems for the production of thermal and electric energy in Kuzbass", Natural Gas Industry, Special Issue № 672, 2012. - P. 62-63.

[14]Mining encyclopedia [Electronic resource]: [official. website] // 20082015. - Access: URL: http: //www.mining-eng.ru/u/uglegaz/ free Coalgas (reference date 10/05/2016).

[15]CJSC "Gazeta.ru" [Electronic resource]: [official. website] // 1999-016. Access: URL: http: // www.gazeta.ru/business/ 2015/01/26/6327017.html/ free - 130 budgets of Russian under the ground (reference date $12 / 05 / 2016)$ 